\title{
下大静脈浸潤癌手術における体外循環方法の検討 下大静脈腫煌栓を伴う腎癌手術における
} $\mathrm{V}-\mathrm{V}$ バイパス循環補助の有用性について—

\author{
植田隆介 西田雅彦 高見 宏 ${ }^{1)}$ 平石泰三 ${ }^{1)}$ 目黒則男 ${ }^{2)}$ 木内利明 ${ }^{2)}$ \\ 宇佐美道之 ${ }^{2)}$ 和泉匡洋 ${ }^{3)}$ 淡田修久 ${ }^{3)}$ 神原紀子 ${ }^{4)}$ 谷上博信 ${ }^{4)}$ 岸 義彦 ${ }^{4)}$
}

\begin{abstract}
要旨 下大静脈 (IVC) 浸潤を伴う癌に対する切除と IVC 再建術では、安定した循環動態の確保が困 難であり、至適補助手段はいまだ確立されていない。我々は IVC 浸潤を伴う腎癌に対する癌切除・ IVC 再建術において、大腿静脈脱血 - 内頸静脈送血の V-V バイパスを補助循環として 6 例に用いた。 $\mathrm{V}-\mathrm{V}$ バイパス回路は遠心ポンプを組み込んだ閉鎖回路に、IVC 切開時の出血に備えて吸引回路を接 続したものを使用した。灌流指数は V-V バイパス開始前の血圧を維持するように送血量を調節し、 結果として $0.8 \sim 1.0 \mathrm{~L} / \mathrm{min} / \mathrm{m}^{2}$ で適正な血圧を維持することができた。死亡例および重篤な合併 症を起こした症例はなく、また、V-V バイパス中の循環動態は安定していた。IVC 切開時に多量の 出血が起こった場合には、吸引回路で回収して迅速に閉鎖回路に返血できたので、安定した循環動 態を維持することができた。IVC 浸潤を伴う腎癌に対する切除・再建術において、V-V バイパスを用 いた補助循環は安定した循環動態下で手術を行うのに有用であった。
\end{abstract}

索引用語：V-V バイパス、下大静脈腫崵手術、腎癌

Extracorporeal circulation for inferior vena cava invading cancer resection

- Efficacy of veno-venous bypass support during resection and reconstruction of inferior vena cava invaded by renal cancer -

Ryusuke Ueda, Masahiko Nishida, Hiroshi Takami ${ }^{1)}$, Taizo Hiraishi ${ }^{1)}$, Norio Meguro ${ }^{2)}$, Toshiaki Kinouchi ${ }^{2)}$, Michiyuki Usami ${ }^{2)}$, Masahiro Izumi ${ }^{3)}$, Nobuhisa Awata ${ }^{3)}$, Noriko Kanbara $^{4)}$, Hironobu Tanigami ${ }^{4)}$, Yoshihiko Kishi ${ }^{4)}$

Key words : veno-venous bypass, inferior vena cava surgery, renal cancer

[J Extra-Corporeal Technology 35(1) : 23-28, 2008]

\section{I . 緒 言}

下大静脈 (以下、IVC) 浸潤癌の切除術では、IVC 遮断中の循環動態維持や IVC 切開時の出血など問題 点が多い。我々は、IVC 浸潤を伴った腎癌や肝癌な どに対して腫瘍切除とともに IVC 浸潤部の合併切除 と IVC 再建を、体外循環を用いて積極的に行ってき た ${ }^{1-2)}$ 。体外循環方法は IVC 浸潤部位、特に腫瘍栓 頭側先端レベルによって異なり単純遮断、 $\mathrm{V}-\mathrm{A}$ バイ

○大阪府立成人病センター 中央手術科 $\mathrm{CE}$ 室

植田隆介（Ryusuke Ueda）

于 537-0025 大阪市東成区中道 1-3-3

Department of Clinical Engineering, Osaka Medical Center for Cancer and Cardiovascular Diseases

1-3-3, Nakamichi, Higashinari-ku, 0saka, 5370025, Japan

1）大阪府立成人病センター

2)

3)

同

同

同
心臟血管外科

泌尿器科

循環器内科

麻酔科
パス、心停止を用いた完全体外循環や V-V バイパス などがある ${ }^{3)}$ 。

IVC 浸潤癌の手術におけるこれら種々の体外循環 方法の中で、IVC 腫咟栓先端が横隔膜よりも尾側に ある腎癌に対する手術において、我々は $V-V$ バイパ スを用いることで安定した循環の維持と出血に対す る対応ができた ${ }^{4)}$ 。そこでこれらの症例において、 体外循環の具体的な工夫、問題点、有用性などにつ いて検討した。

\section{II. 対 象}

2000 年から 2007 年までに当センターで行った IVC 浸潤腎癌のうち、V-V バイパス補助下に IVC 腫 瘍栓摘出と IVC 再建を行った 6 例を対象とした。患 者年齢は 62 歳〜 76 歳 (平均 $69.2 \pm 6.2$ 歳) であり、 6 例ともに男性であった。BSA は $1.64 \pm 0.17 \mathrm{~m}^{2}$ であっ た。IVCの浸潤形態は 6 例ともに腫瘍化した腎臓の 腎静脈から、癌が IVC に侵入した IVC 内腫瘍栓の形 態であった。IVC 壁の癌浸潤は患側の腎静脈および 
表 1 対象症例と体外循環および補助手段

\begin{tabular}{|c|c|c|c|c|c|c|c|c|c|c|c|}
\hline 症例 & $\begin{array}{l}\text { Age } \\
\text { (才) }\end{array}$ & Sex & $\begin{array}{l}\mathrm{BSA} \\
\left(\mathrm{m}^{2}\right)\end{array}$ & 蜘患 & $\begin{array}{c}\text { IVC内腫摚栓 } \\
\text { 先進部位 }\end{array}$ & $\begin{array}{c}\text { IVC } \\
\text { 再发法 }\end{array}$ & $\begin{array}{c}\text { V-Vハイイ゚ス } \\
\text { 眭間 (分) }\end{array}$ & $\begin{array}{c}\text { IVC遮激 } \\
\text { 時間 (分) }\end{array}$ & $\begin{array}{l}\text { Pump } \\
\text { Sucker }\end{array}$ & Pringle法 & $\begin{array}{l}\text { Temporary } \\
\text { IVC Filter }\end{array}$ \\
\hline 1 & 74 & N & 1.60 & 右骨供 & 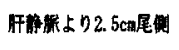 & 直接維合 & 24 & 22 & - & - & - \\
\hline 2 & 66 & II & 1.50 & 左鳘瘏 & 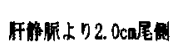 & パッチ再建 & 60 & 55 & + & $+($ 肝阻血10分) & + \\
\hline 3 & 63 & H & 1.87 & 在䇶右 & 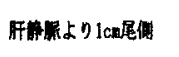 & パッチ再建 & 60 & 55 & + & $+($ 肝阻血 6 分) & - \\
\hline 4 & 62 & N & 1.72 & 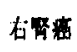 & 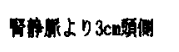 & パッチ再建 & 52 & 45 & + & - & - \\
\hline 5 & 76 & H & 1.52 & 左筩事 & 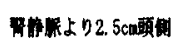 & パシチ再建 & 41 & 39 & - & - & - \\
\hline 6 & 74 & $n$ & 1.59 & 左简富 & 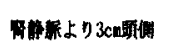 & パッチ再建 & 34 & 29 & - & - & - \\
\hline & \pm 6 & & $3 \pm 0$. & & & & $45.2 \pm 14.7$ & $40.8 \pm 13.5$ & & & 0. \\
\hline
\end{tabular}

その周囲の IVC 壁に限局していた。IVC内腫嘎栓先

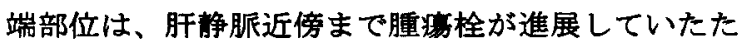
めに肝莄の剥離・脱転を要したものが 3 例（症例 1 〜3)、また残りの 3 例（症例 $4 \sim 6$ ）は盈觧脈開口 部付近にとどまるものであった（表 1)。

\section{III. 方 法}

\section{V-Vバイパス回路}

V-V バイパスの駆動は Medtronic 社製バイオコン ソール 550 型の遠心ポンプを用いた。また回路は 薏心ポンプを組み込んだ左心バイパス用閉鎖回路 CCS4（3/8インチ，ヘパリンコーティング）を使用 した（図 1)。この閉鎖回路には人工肺が組み込ま

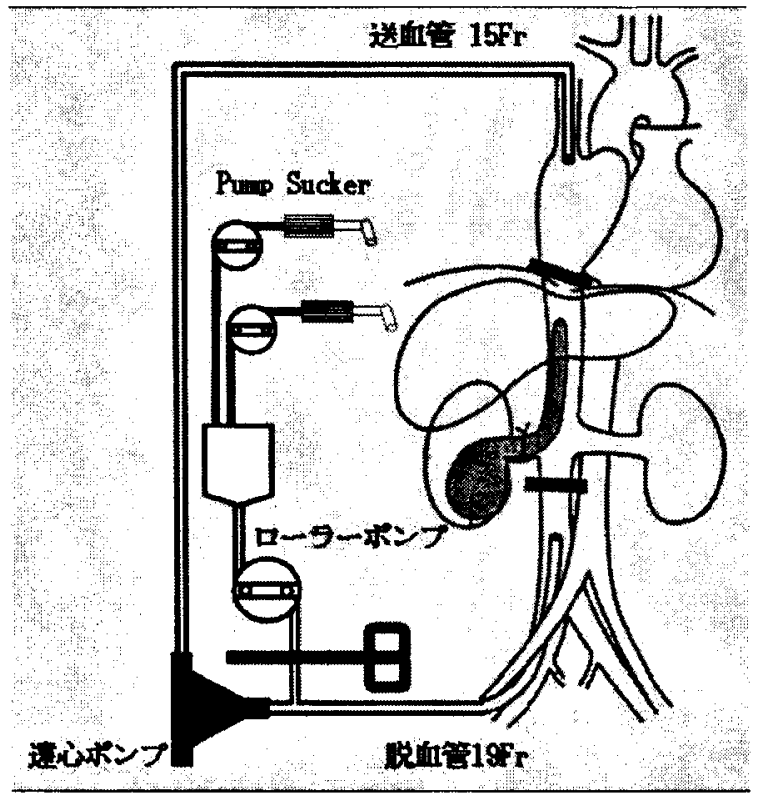

図1 V-Vバイパス回路の模式図
れていないため、プライミング時のエアー抜きがや や煩雑であった。具体的には脱血回路を点滴輸液 バックの下端に接続し、送血回路を輸液バックの上 方に返して、减速回転しながら回路内エアーを除去 した。V-Vバイパス回路の笨備にはおよそ $20 〜 30$ 分を要した。

IVC の末梢側遮断鋁子を斜めにクランプして対側 （健側）の督静脈遇流血を IVC 内脱血管に導くこと ができる場合（図 2a）には、IVC 切開部からの出血 が少なく吸引回路が必要ではないために体外循環回 路は閉鎖回路となる。一方、IVC 末梢側遮断銝子を 左右腎静脈の末梢側でクランプせざるをえない埸 合（図 2b）には、IVC 切開口から大量の対側堅静脈 血が流出するため吸引回路が必要となる。そこで 2 本の吸引回路とカルディオトミーリザーバーをロー

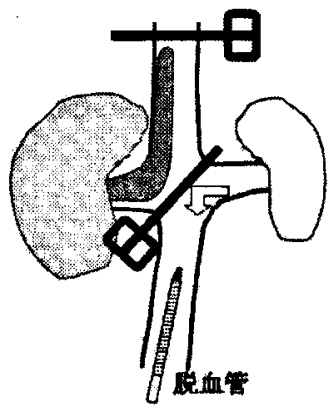

(a)

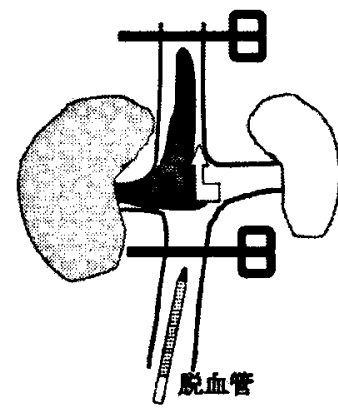

(b)
図 2 IVC 遮断部位

（a）IVC 末梢側遮断鉗子を斜めにして、対側 堅静脈血をIVC 脱血管に监ける場合は、出血 が少ないため pump sucker が不要となる。

（b）IVC 末梢側遮断鉗子を左右紫静脈の末梢 遮断する場合には IVC 切開口より出血が多い ため pump suckerが必要となる。 
ラーポンプを介して V-V バイパスに接続し、半閉鎖 回路とした（図 1)。これにより大量出血した場合 の循環血液量の維持が難しい左心バイパス用回路の 問題点を補った ${ }^{5)}$ 。また閉鎖回路への接続ラインは 遠心ポンプ入口側であり常に陰圧となっているため 空気混入の危険性がある。これを考虑し、使用時以 外はラインをチューブ鉗子にて遮断した。

Pump sucker 回路を使用する場合はへパリン投与 量を $3 \mathrm{mg} / \mathrm{kg}$ とし、 pump suckerを要しない場合は ヘパリンを $1 \mathrm{mg} / \mathrm{kg}$ とした。

\section{V-V バイパス手技}

全身麻酔導入後にまず右内頸静脈と右大腿静脈 に八光エラスター $(19 \mathrm{G}, 90 \mathrm{~mm}$, 八光社製 $)$ を穿刺留 置した。開腹して腎癌周囲を剥離したのち、へパ リンを静注して右大腿静脈より PCPS 脱血管 (19Fr. Medtronic 社製）を腎静脈下まで術野より触診で誘 導しながら挿入した。次に右内頸静脈より PCPS 送 血管（15Fr. Medtronic 社製）を上大静脈から右心 房付近まで挿入して、回路と接続し、遠心ポンプを $1000 \mathrm{rpm}$ 前後で回転させ体外循環を開始した。灌流 指数をおよそ $1.0 \mathrm{~L} / \mathrm{min} / \mathrm{m}^{2}$ までポンプ流量を上げ て V-V バイパス循環が維持できることを確認してか ら IVC を遮断した。この後は開始前の血圧を維持す るように送血量をコントロールした。

\section{IVC 再建法}

IVCへの浸潤は患側腎静脈の開口部付近のIVC 壁、 および IVC 内に侵入したリップスティック型の腫瘍 栓であり、これらを en blocに切除した。IVCにで きたおよそ0.8〜 3cm 径の欠損孔は、GoreTex パッ チを用いて、あるいは直接縫合閉鎖した。

症例 2 については腎動脈の embolizationを術前 に行っていたため、腫湯組織の脆弱化によって腫場 栓の脱落や肺塞栓の可能性が高いと考えられた。そ こで一時的 IVCフィルターを挿入して腫瘍栓の脱落 を防いだ ${ }^{6)}$ この IVCフィルターは IVC 切開ロより 切り取って腫瘍栓とともに摘出した ${ }^{7)}$ 。

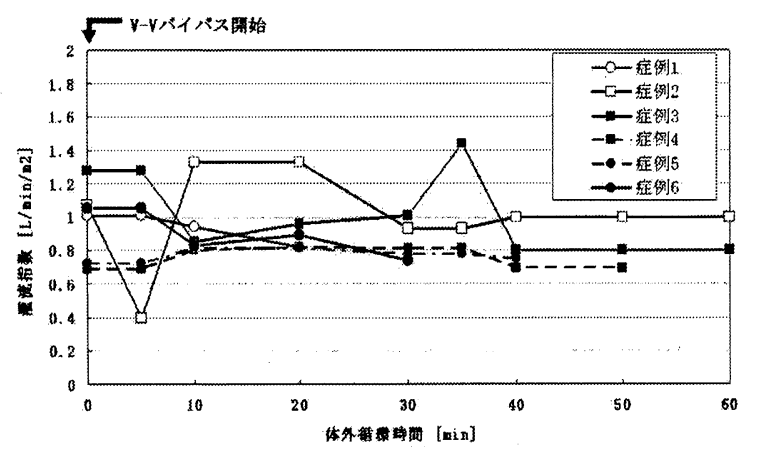

図 $3 \mathrm{~V}-\mathrm{V}$ バイパス中の灌流指数

\section{III. 結 果}

体外循環時間 $47 \pm 15.2$ 分、IVC 遮断時間は 43.2 \pm 13.7 分であった。対側腎静脈血や肝静脈血の出 血に対処するために pump sucker 吸引回路を使用し

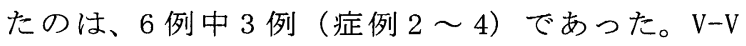
バイパス開始前の血圧を維持することを目標に送血 量を調節し灌流指数を $0.4 \sim 1.42 \mathrm{~L} / \mathrm{min} / \mathrm{m}^{2}$ の範囲 で増減することによって比較的安定した血圧を維持 できた（図 3，4）。V-V バイパス中の灌流指数の目 安は $0.8 \sim 1.0 \mathrm{~L} / \mathrm{min} / \mathrm{m}^{2}$ であった。遠心ポンプの回 転数は $1,000 \sim 2,000 \mathrm{rpm}$ 、脱血不良はなく回路内 圧は遠心ポンプ出ロで 50 〜 $60 \mathrm{mmHg}$ であり異常な上 昇はなかった。

腫瘍栓が肝静脈口に達していた症例 2 と 3 では、 一時的に Pringle 法 8) にて肝静脈還流血を減少さ せるとともに、 pump suckerを用いることによって 視野を確保して IVC 切開口の縫合を行うことで循環 を維持することができた。

$\mathrm{V}-\mathrm{V}$ バイパス回路には熱交換器を組み込んでいな いため長時間の体外循環において体温の低下が㲘念 され、症例 3 と 4 において $\mathrm{V}-\mathrm{V}$ バイパス開始時より $1{ }^{\circ} \mathrm{C}$ 体温低下が見られた。体温低下は平均 $0.6 \pm$ $0.3^{\circ} \mathrm{C}$ あ゙あた（表 2 )。

6 症例とも V-V バイパス中に循環動態は図 4 のよ うに安定しており、体外循環終了後にプロタミン中 和して、止血に苦慮することもなかった。

術後は 6 例とも重篤な合併症は起こさず退院し た。平均 ICU 滞在日数は $1.7 \pm 0.8$ 日、手術日から の退院日数は $31.2 \pm 17.8$ であった。退院後 4 ケ月 から 38 ケ月の術後経過観察期間において全例生存 が確認されている（表 2）。

\section{IV. 考 察}

我々はIVCに浸潤した癌に対して、遠隔転移がな く原発腫瘍が切除可能な場合は、積極的に IVC 合併 切除を併施して腫瘍の全切除を行ってきた ${ }^{1-2)}$ 。最 近の約 10 年間に IVC 浸潤を伴った腎癌 (8 例)、肝 癌 (5 例)、精巣癌 (2 例)、副腎癌 (1 例) など、計

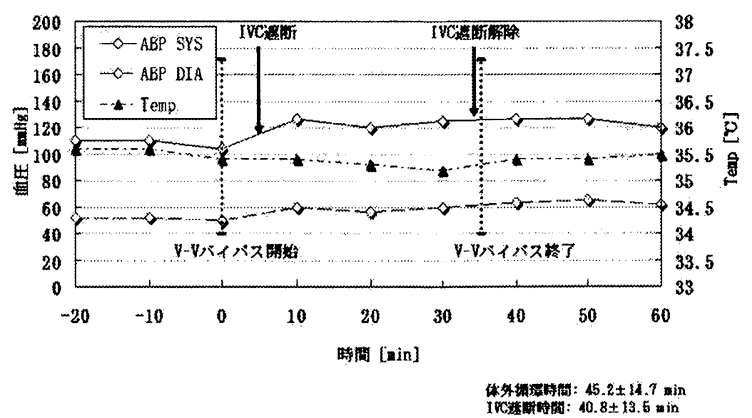

図 $4 \mathrm{~V}-\mathrm{V}$ バイパス中の典型的な循環経過（症例 6） 
表 2 対象症例の結果

\begin{tabular}{|c|c|c|c|c|c|c|c|}
\hline 症例 & $\begin{array}{l}\text { ポンプ開始時 } \\
\text { 中枢温 }\left({ }^{\circ} \mathrm{C}\right)\end{array}$ & $\begin{array}{l}\text { ボンプ終了時 } \\
\text { 中枢温 }\left({ }^{\circ} \mathrm{C}\right)\end{array}$ & 体温低下 $\left({ }^{\circ} \mathrm{C}\right)$ & $\begin{array}{c}\text { ICL滞在日数 } \\
(日)\end{array}$ & $\begin{array}{c}\text { 術後入院日数 } \\
\text { (日) }\end{array}$ & $\begin{array}{c}\text { 術後 } \\
\text { 観察期間 }\end{array}$ & 予後 \\
\hline 1 & 36.5 & 36.0 & 0.5 & 2 & 17 & 38ヶ月 & 生存 \\
\hline 2 & 36.2 & 35.5 & 0.7 & 3 & 41 & 33ヶ月 & 生存 \\
\hline 3 & 35.1 & 34.1 & 1.0 & 2 & 13 & 28ヶ月 & 生存 \\
\hline 4 & 36.6 & 35.6 & 1.0 & 1 & 47 & 27ヶ月 & 生存 \\
\hline 5 & 37.3 & 37.0 & 0.3 & 1 & 16 & 9ヶ月 & 生存 \\
\hline \multirow[t]{2}{*}{6} & 35.4 & 35.2 & 0.2 & 1 & 53 & 4ヶ月 & 生存 \\
\hline & & & $0.6 \pm 0.3$ & $1.7 \pm 0.8$ & $31.2 \pm 17.8$ & \multicolumn{2}{|c|}{ Mean $\pm S D$} \\
\hline
\end{tabular}

18 例の悪性腫瘍に対して、原発腫瘍と IVC 浸潤部 を en bloc に切除して IVC を再建する手術を行って きた。癌が浸潤した IVC 壁の切除並びに IVC 腫㿉栓 の摘出にあたっては、種々の体外循環を用いた補助 手段が必要となる。この体外循環の方法は IVC 腫瘍 栓の頭側先端部位によって異なり、右心房に腫瘍栓 が進入している場合には心停止法を用いた完全体外 循環が必要となるが、腫瘍の先進部が横隔膜レベル よりも尾側の場合は、たとえ肝静脈開口部に近接し ていても V-Vバイパスを用いて手術が遂行できた ${ }^{4)}$ 。 IVC 浸潤を来たした 8 例の腎癌のうち、2 例は腫瘍 栓が右心房内まで進入していたため、完全体外循環 下心停止法を用いたが、他の 6 例は腫瘍先進部が横 隔膜よりも尾側であったため $V-V$ バイパス補助下に 手術を行った。この 6 例では、補助手段や手術手技 がほぼ定型化して円滑に行えるようになったため今 回の研究対象としたものである。

腎癌はたとえIVCに浸潤していても、その部位を 含めて腫瘳を全切除することによって大幅に予後が 改善されるとの報告があり、したがって体外循環を 用いてでも、可及的に IVC 浸潤部を全切除すること

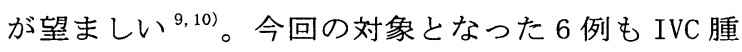
瘍栓を含めた腫瘍全切除によって生命予後は改善さ れ、術後観察期間の 4 〜 38 ケにおいて全例が生 存している。

IVC 浸潤形態が比較的単純な症例では体外循環を 用いずに単純遮断下に切除再建術を行うことも可能 であり、我々もIVC腫瘍栓を持った肝癌の 1 例に単

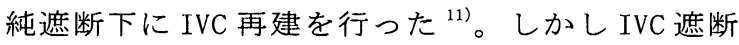
中は、大量の輸液負荷やカテコールアミンなどの昇 圧剤投与を行いながら急いで IVC 再建を行わねばな らず、IVC 遮断許容時間には限界があると考えられ た。また IVC 浸潤を伴った他の肝癌症例において、 一時的に IVC を離断してしまったためにショックに
陥つた事例を経験した（図 5 )。そしてこのショッ クは $\mathrm{V}-\mathrm{V}$ バイパスを急遽開始することによって劇的 に改善した。このような理由から IVC 再建を落ち着 いて安全に行うためには、V-Vバイパスによる循環 補助が有用であると考えられる。

腎癌摘出術の術後は片腎になるため、対側（健側） の腎臓に対して術中に阻血障害や静脈栕血による障 害を加えずに保護することが望ましい。この目的で 我々は、対側の腎動脈と腎静脈を遮断せずに IVC 再 建術を行うようしている。対側腎静脈血が IVC 切開 ロから溢出する場合は、 pump sucker で対応した。

IVC 腫癔栓の先進部位に関しては横隔膜よりも 尾側であれば、たとえ肝静脈開口部付近に腫瘍栓 が達していても、V-V バイパス補助で IVC 再建は可 能であった。対象症例 6 例のうち 2 例（症例 2 と 3）では腫瘍栓が肝静脈口に達していたが、一時的 にPringle 法にて肝静脈灌流血を減少させるととも に、 pump suckerを用いることによって IVC 再建が 可能であった。このようなケースに対して超低体

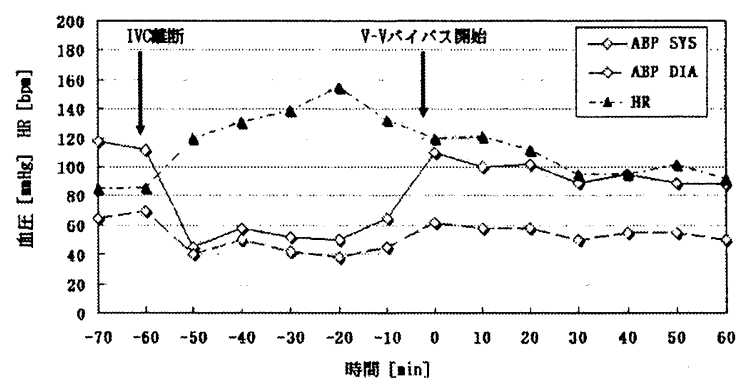

図 5 IVC 離断によりショックとなった IVC 浸潤を 有する肝癌の 1 例

このショックは V-V バイパスの開始によって 劇的に改善した。 
温下循環停止法を用いるとの報告も見られるが ${ }^{12)}$ 、 我々はより簡便な $\mathrm{V}-\mathrm{V}$ バイパスにて対応できると考 えている。

癌の切除術において体外循環や pump suckerを用 いると、癌組織の全身への散布・播種が起こるので はないかとの䀣念がある。この点に関して我々は初 期の症例において、カルディオトミーリザーバー を解体して顕微鏡検索を行ったところ、癌細胞塊

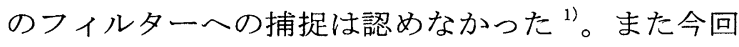
の腎癌症例 6 例は全例長期に生存していることもま た、体外循環による腫瘍の散布や遠隔転移は起こ りにくいことを示唆している。しかし、腫瘍栓が 脆弱な場合は、術中の操作によってちぎれて肺塞 栓や肺転移を起こす可能性がある。特に腎動脈の embolizationを術前に行っている症例では、腫瘍 栓の脆弱化によってこの可能性が比較的高い。この ような場合は、症例 2 のように、一時的 IVCフィル ターを挿入して腫場栓の脱落を防ぐことが必要と考 えられる ${ }^{6)}$ 。

$\mathrm{V}-\mathrm{V}$ バイパスは左心バイパス用の閉鎖回路を用い ており、人工肺や動脈フィルターを組み込んでいな いために、プライミング時のエアー抜きには少し 手間がかかる。Pump sucker とカルディオトミーリ ザーバーは症例によっては不要となることもある が、セットアップに時間がかかるためにあらかじめ 閉鎖回路にローラーポンプを介して接続しておく方 が速い対応ができると考えられる。

$\mathrm{V}-\mathrm{V}$ バイパスの灌流量は、バイパス開始前の血圧 を維持するようにコントロールしたが、この 6 例の 経験からその灌流指数はおよそ $0.8 \sim 1.0 \mathrm{~L} / \mathrm{min} / \mathrm{m}^{2}$ であった（図 3 ）。V-Vバイパスが長時間となると、 体外循環中の低体温もまた問題となる。腎癌のIVC 浸潤は比較的シンプルであり、IVC 再建に要する時 間は長くても 1 時間以内であったため、体外循環 中の低体温は軽微であり、熱交換器は必要なかっ た。しかし IVC 浸潤形態が複雑な肝癌症例などにお いて、長時間の体外循環が予想される場合には熱交 換器を回路に組み込んでおくほうが無難と考えられ る $^{5)}$ 。

送脱血管の挿入は Seldinger 法によって行ってい る。脱血管の挿入は比較的容易である。しかし上大 静脈への送血管の挿入は、blind で over the wire 法で送血管を挿入しなければならないためやや難し い。対象の 6 例中の 1 例において、このワイヤーが 脱落したため送血管挿入に難渋し、皮膚切開を加え て直視下に右内頸静脈に送血管を挿入しなければな らなかった。ワイヤーを適正な深さまで挿入して over the wire 方式でカテーテルを上大静脈から右 心房に安全かつ確実に挿入するのは、注意深い技術 を要する手技と考えられた。

\section{V. 結 論}

IVC 浸潤を有する癌の切除・再建術においては、 IVC 腫瘍栓の頭側先進部位に応じた適正な体外循環 方法の選択、IVC 切開口からの出血への対処、腎藏 や肝臓の保護等に関して慎重な対応が必要である。 本 V-V バイパス法は横隔膜よりも尾側までの IVC 浸 潤を有する腎癌の手術においては、安定した循環の 維持と出血への対処の面等において有用かつ安全な 補助手段と考えられた。

\section{- 参考文献}

1）平石泰三, 小林亭, 櫻井温, ほか：下大静脈進展を 伴う後腹膜腫瘍の外科治療における体外循環の応用. 日心外会誌, 21(6)；540-543, 1992.

2）平石泰三, 高見 宏: 下大静脈進展を伴う悪性腫瘍 に対する体外循環の応用。第 107 回日本外科学会定 期学術集会, 2007 年 4 月, 大阪.

3) Kaplan S, Ekici S, Pasaoglu I, et al.: Surgical management of renal cell carcinoma with inferior vena cava tumor thrombus. Am J Surg, 183;292-299, 2002.

4) Belgrano E, Liguori G, ZingoneB, et al. :Modified pump-driven venous bypass in surgery for renal cell carcinoma (RCC) involving the inferior vena cave (IVC). World J Urol, 20(1);56-58, 2002.

5）阿部稔雄, 上田裕一 編：最新人工心肺理論と 実際. 第二版、名古屋、名古屋大学出版社. 2003 . p. 205-206

6) Tanaka Y, Kawaguchi M, Furuya H, et al. ;Combined used of transesophageal echocardiography and basket catheter can prevent tumor embolism in apatient with renal cell carcinoma. Anesthesiology. 89;1015-1017, 1998.

7）硲光司, 御村光子, 並木昭義, ほか: Temporary IVC filter が抜去不能となった腎腫瘍の一症例. 循環 制御, $19(4) ; 561-564,1998$.

8) Pringle JH: Notes on the arrest of hepatic hemorrhage due to trauma. Ann Surg, 48;541-549, 1908.

9) Skinner DG, Pritchett TR, Lieskovsky G, et al. : Vena caval involvement by renal cell carcinoma. Surgical resection provides meaningful long-term survival. Ann Surg, 210;387-394, 1989.

10) Hatcher PA, Anderson EE, Paulson DF, et al. : Surgical management and prognosis of renal cell carcinoma invading the vena cava. J Urol,

$145 ; 20-24,1991$.

11) Uemura M, Sasaki Y, Imaoka S, et a1. :Surgery for hepatocellular Carcinoma with tumor thrombus extending into the right atrium: Report of a successful resection without the use of Cardiopulmonary bypass. Hepatogastroenterology, 
$51 ; 1259-1261,2004$.

12) Novick AC, Kaye MC, Cosgrove DE, et a1.: Experience with cardiopulmonary bypass and deep hypothermic circulatory arrest in the management of retroperitoneal tumors with large vena caval thrombi. Ann Surg , 212;472-477, 1990.

[本論文は、第 33 回日本体外循環技術医学会 